\title{
TEN TOP PROBLEMS OF EDUCATION. FROM COGNITIVE DISSONANCE TO THE ALGORITHM OF THE FUTURE RENAISSANCE
}

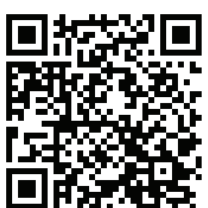

To cite this article:

\author{
Petro Saukh, Dr. Sc., Prof. \\ Academician-Secretary, Department of Higher Education, \\ National Academy of Educational Sciences of Ukraine, \\ Kyiv, Ukraine \\ 4813764@ukr.net \\ https://orcid.org/0000-0003-4366-2496
}

\author{
Liudmyla Chumak \\ Professor, Department of the English Language, \\ Ivan Franko Zhytomyr State University, \\ Zhytomyr, Ukraine \\ liudmylachumak@gmail.com \\ https://orcid.org/0000-0001-6631-3403
}

\author{
Saukh, P. \& Chumak, L. (2018). Ten top problems \\ of education. From cognitive dissonance \\ to the algorithm of the future renaissance. \\ Education: Modern Discourses, 1, 24-31. \\ https://doi.org/10.32405/2617-3107-2018-1-3
}

\begin{abstract}
The article analyzes the radical transformations of classical education, characterizes the peculiarities of foreign and national system of education reaction to the challenges of a modern innovative society. It has been outlined that in many countries of the European Union, North America (the USA, Canada), the East (Japan, China), new schemes for the division of higher education programs into professional and academic ones are being developed and implemented, a system of narrow-profile higher educational institutions is being formed, research and corporate universities come into being. At all levels of higher education the aims, theory and practice of training prospective specialists are reconsidered. In addition, it has been shown that in Ukraine, modern problems of reforming education, on the contrary, lack system and consistency, in programs and slogans of subjects of educational policy there are often elements of populism, and setting of unrealistic tasks. As a result, many participants of the educational process have a sense of cognitive dissonance both when trying to assess the true state of the academic environment and evaluate the models that are offered. Based on comprehension of the most important points of bifurcation in modern Ukrainian education, ten key problems are identified and characterized. It is proved that solving them and ensuring the renaissance of education is possible, at least, based on three viable steps: introduction of a new organizational and economic mechanism for innovative development of education; reconstruction of the content and methodological resources of education; audit of the academic environment and optimization of the network of higher educational institutions.
\end{abstract}

Key words: national system of education; quality of education; cognitive dissonance; exponential technologies; social and educational determinism; optimization of the network of higher educational institutions; university 2.0. and 3.0. 


\section{INTRODUCTION. PROBLEM STATEMENT}

In the last few years the problems of education get particular topicality in the speeches and publications of Ukrainian philosophers and sociologists, teachers and psychologists, journalists and politicians, various kinds of experts. It is absolutely obvious that this happens not by chance or because of the following intellectual fashion, fertilized by political expediency. It is based on new trends in the global civilization process, which require radical changes in education in the context of exponential technologies. An absolute majority of Ukrainian and foreign scientists note, that present-day educational system does not meet the requirements of time. It is criticized and a new image that is more adequate to modern socio-cultural situation is simulated. But these non-classical outlines of the architectonics of education do not always inspire hope that we are on the right road. The neoliberal context of reformation of education (commodification of knowledge, commercialization and mass education of higher education, etc.) brings it out of traditions of the historical mission. The Professor of Cultural Studies at the University of Manchester, Terry Eagleton, not without reason speaks of "the slow death of the university", describing the details of educational reforms in the West (Eagleton, 2015).

Many of the well-known teachers-theorists express their thoughts that in some thirty years the great university centers, the famous ones will become relic, or even perhaps cease to exist as independent institutes and the community of scientists. They are believed to be "the bulwark of arrogance and successful generations" in the past, and today they do not compete with narrow-profile educational institutions, pragmatically oriented to specific technologies that the innovative society requires (Collini, 2011). In other words, it is not just about the "bankruptcy of the historical mission of universities but it also demonstrates the confusion to outline of the "expected renaissance" of education.

Despite some exaggeration of these predictions, there is a grain of truth in that, and there are indeed many reasons for such anxiety. What should our reaction to these processes be, no one knows for sure. One thing is clear that if we did not think of them no matter how much we would talk over the limitations of postmodern education that "ignores the meaningful values of human life" and minimizes opportunities of sociocultural renovation of a person, it would be silly not to notice these radical changes or resist them. It is equivalent to suicide to remain classical university education unchangeable, continue to graduate specialists who are deeply aware of reality, its fundamental laws, who are philosophical and humanistic educated but little able to perform innovative socio-professional roles. In this situation to ask the questions "how", "who", "what for", to attempt to monetize education, to "deal a fatal blow" that has been cherished for centuries, means that kind of logic due to which the lightning conductor is not built, but the Society of lightning struggle is called to create (Nikol'skij, 2010).

On the contrary, all this requires an effective response of traditional education, which must reasonably combine the utilitarian pragmatics of professional training of a specialist with the "pragmatics" of fundamental knowledge thanks to which an innovative society will provide the needs of civilizing development, keep and increase its humanistic potential, fill the human life with meanings and values. It should be understood: the world no longer appreciates what we know, it is interested in what we can do with this knowledge. To be honest to the end, our education system is hopelessly outdated. School and life, university and industry are two opposite, completely unrelated things. Their role resembles one of the functions of the stewardess, who is obliged to talk 
about accident preventatives during the flight. Almost nobody listens to her as there were no such cases when one did everything according to the instructions and then said: the plane fell, all died, and I stayed alive, because I listened carefully to the stewardess. Or how to explain in the context of modern education system functioning that at the age of three-five years old $98 \%$ of children are able to think non-typically, originally, to be so to say "Geniuses of divergent thinking" and after five years of school education they remain only $32 \%$, and by the time to finish school there are only few of them. It is obvious that the standardized educational process kills the innate human peculiarity. However, it is quite possible to reform this paradoxical problem as it is proved by the educational systems of Singapore and Finland. Ken Robinson, an International Education Advisor (USA) rightly accentuating the requirement for a new concept of the so-called "ecology of mankind" emphasizes that it is necessary today to change the attitude towards the wealth of human capabilities, because "modern system of education exploits the human mind" the same way as Earth resources, exceptionally for a particular purpose.

This principle will not work in the future. It is time to review the way we teach our children and begin to reveal their creativity. Today we can already predict with a great deal of probability that the concept "profession" will disappear. It will be replaced with the system of competencies. Over the past 100 years nearly 600 occupations have disappeared another 1000 have greatly transformed. Apparatus "Hadrian-X" lays a thousand bricks per hour. This is 8-10 times more that a person can do. There is a rhetorical question: how long will the profession of a stonemason exist ...? About 200 new professions, penetrated by the system of competences of the future (complex multilevel problem solving, critical thinking, creativity, emotional intelligence, etc.) are expected to appear by the year 2030 .

According to experts, in every ten years, more than $80 \%$ of the technologies and equipment used at present become outdated. By that time, four out of every five workers will have education, received ten years before. And if not opportunely take part in the system of new knowledge mastering, competences and skills, there is a risk to stay on the edge of mainstream development.

Educational systems of different countries of the world respond to these problems differently. Some of them are passively concerned; others actively transform them into the requirements of a modern, innovative society. In many countries of the European Union, North America (USA, Canada) East (Japan, China) the new schemes of high school programs division into professional and academic are actively being developed and implemented, the common interests of secondary and higher educational institutions are coordinated, which are considered as elements of a unified, holistic training of human capital. On this basis, systemic restructuring of education is carried out, that is at most close to the requirements of an innovative society in the context of exponential technologies. Gradually classical universities change their image; a system of narrowprofile universities is being formed; research and corporate institutions of higher education come into being. The aims, the theory and practice of future specialists' training are reinterpreted at all levels of education.

This difficult situation generally finds understanding at the basic levels of organization of Ukrainian national education. The reformation of education, initiated with the proclamation of Independence of Ukraine was not by chance aimed at democratization, decentralization and scientific and practical orientation. However, despite the fact that high qualitative, competence-oriented education was proclaimed of a national priority, 
no serious changes in this area occurred. In each of the sections of education system, appeared new, even more complicated problems stipulated by the necessity for structural reformation, spontaneous changes in educational priorities, inadequate financing and unsystematic character of reforms. Trying to improve the national education system, we did not care and, unfortunately, we do not care that the medicine we use could not be even more dangerous than the disease itself (Saukh, 2012: p. 4).

Today, in Ukraine, many people have a sense of cognitive dissonance, when trying objectively to assess the true state of the academic surroundings, as well when trying to assess the methods offered. The problem of the most of the reformative initiatives is that their authors practically do not estimate the maximum possible deadlines for the implementation of the reform components, which may have unfortunate results. Sometimes it seems that all this is done to follow the fashion.

Let us try, interpreting the most important points of the bifurcation of our education, to define problem elements in the context of the Renaissance algorithm of cultural and civilizational self-identification of education and the needs of an innovative society. There are at least ten of them:

(1) Attitude of the authorities to education as to a "consumable" part of the state budget. As a result: outdated infrastructure of the higher education institutions; imbalance in the financing of various educational needs $(68.7 \%$ of wage financing, $31 \%$ of scholarships, and $0.3 \%$ of capital expenditures). Until this imbalance is resolved, our curriculum will become immensely out of date, especially those that require modern equipments; there will be a financial and material dependence of education institutions on parents support; there will be no stimulation of research activities of universities, which in their turn is an obstacle to the introduction of innovative technologies and teaching aids.

(2) Inconsistency and unsystematic character of transformations and the inability to orient oneself in time when implementing the outlined model of educational reform. A rigidly centralized system of education, where the Center's principle dominates in the pedagogical community and educational institutions, immobilizes their initiative, and the politicians determine the nature and sequence of the reforming. At first, we start to reform higher education, and then secondary education, having no doubts that higher education is just the tip of the iceberg. As a result, today we propose serious amendments to the Law of Ukraine "On Higher Education". Similar cognitive distortions, that is to say peculiar traps, errors, that happen, because of unconsidered assumptions, are carried into practice for one reason - analytic dysfunction.

(3) Lack of a new economic model of education, based on multi-vector financing and a well-considered system of economical attitude to state finances. The efficiency of education does not depend exclusively on the increase of financing (although it is of great importance), but mainly on the extremely low productivity of the participants in the educational process. In the general structure of those who work in Ukraine, educationalists account for $15.5 \%$, whereas in Germany $-5.9 \%$, in Poland $-7.4 \%$, in Great Britain $-9.1 \%$, in the United States $-9.1 \%$, in France $-6.4 \%$, that is almost twice as much as in other countries (Robinson \& Aronica, 2016). There is a fair question: why the law of the transition of quantitative changes into qualitative ones does not work here?

(4) The crisis of work motivation, low salary of academic staff and its rapid aging. The salary level in the education system remains significantly lower than in other sectors of economy. The problem with most higher education teaching personnel is that they do not have practical experience in the subject area they teach. For effective work, teachers should 
have 10-15 years of practical experience in the sphere they work in. In addition, Ukraine lacks advanced training programs for higher education teaching staff in schools, companies, business to acquire and improve practical experience, thus "the world of teaching at the university", "the world of production", "the world of school" do not overlap.

(5) The low level of education quality. There is inconsistency between school and university teaching and time requirements. In Ukraine, unfortunately, there is still no understanding of why education is needed and how it can be monetized into highquality human life. Education remains in the strong embrace of the logo-centric model, and in the best case it balances between this model and the liberal (non-classical) one. Here predominates the pedagogy of paternalism, instead of the tolerant pedagogy of cooperation. All the participants of the educational process bring to attention the low quality of education, their opinion is confirmed by numerous sociological researches. However, there is no nationwide system for monitoring and controlling the quality of higher education.

(6) Inconsistency of the alumni and their knowledge and skills to the needs of the labor market. The reason for this problem is the lack of clear planning of young specialists' employment, as well as the unpreparedness of graduates to work in the chosen profession. Employers point out that in order for a young specialist to bring in at least $20-30 \%$ of returns, it is necessary to spend at least 8 months on their professional training in the company. In other words, our education loses its public orientation; it has not learnt to respond promptly to the educational demands of society and employers. We do not have an effective science-based system for monitoring and prediction of the needs of specialists for a region or the country in the whole.

(7) The low level of integration of higher education, science and production. Most institutions of higher education "do not hear" business, and as a result, $91 \%$ of employers pay attention to the lack of practical knowledge among graduates, $25 \%$ of whom are hired for work that does not require their level of education. Therefore, national universities have failed to become the source of competencies, engineering services, and consulting service centers for market players, that is, all that is required by the University 2.0 concept.

(8) Low academic mobility: both internal (within Ukraine) and external (training and internships abroad). The level of soft skills, such as students and faculty foreign language skills, communication skills of students and lecturers reduce access to world educational, scientific and cultural achievements and to their competitiveness in the labor market (both national and global). The recent years increase in the number of students traveling to study abroad is often related not so much to academic mobility but to emigration. Of the 25,000 students studying abroad, in 2009, few returned to Ukraine. In 2017 more than 70 thousand students study abroad, of them 33370 - in Poland. $45 \%$ of parents would like to teach their children abroad.

(9) The deformity of axiological orientation of youth. The craving for power, material well-being and money, as well as gaining success at any price have become the conceptual guidelines. As a result: there is actualization of professions in the system of "man - man", "man - sign system". Modest professional roles in the structure of the labor potential "man - nature", "man - technology", and especially "man - school" no longer suit anybody and are considered the fate of losers. About $50 \%$ of students demonstrate an infantile attitude to the chosen profession. Of the $80 \%$ of school-leavers that become students, only $14 \%$ are going to work according to the specialty (Saukh, 2012). For most, the main motivation is a state scholarship and a diploma. With these values, vital 
imperatives are to some extent linked with corruption and academic insecurity, which, according to sociological research, remain a notable phenomenon in higher education.

(10) The lack of institutional and academic autonomy of higher education institutions. Formally, the Law of Ukraine "On Higher Education" significantly expands the rights and freedoms of universities, however, in this regard, there arise at least two problems: the transference of the law provisions into specific sub-laws, regulations and procedures, and the danger of using the principles of autonomy by individual interest groups, in particular higher university administration. Equally important remains the problem of higher education restructuring, which should conform with the International Standard Classification of Education, that is, differentiate institutions of higher education by types ("A" - for the further education and highly qualified labor and "B" - for the labor market).

In order to ensure the Ukrainian national education renaissance, three important steps are needed. The first step. Social and educational determinism should be the basis for the modernization of Ukrainian society, and it should not be a negation, but a new phase in the development of social and economic determinism. This does not mean the refusal to recognize the decisive role of the economic factor in the development of society, but the recognition of the archival role of education in the development of modern economies as the fundamental basis of social life. Economic relations in education (in particular, higher education) are non-market, and the volume of financing of institutions of higher education does not depend on the quality of educational services. This requires a new economic model of the functioning of education system. Of course, this step involves serious changes in the country's socio-economic policy vector as well as in national policy in general, but it (and perhaps only it) can return respect for education and science in society, eliminate pragmatic and conformist distortions in the minds of young people, instill social optimism in educators and become a prerequisite for Ukraine's innovation and technological breakthrough.

The second step. A systemic, transparent and scientifically based model of education transformation should not only be the subject of public consensus, but also a firm belief in political continuity, when a change of power does not lead to the abolition of certain components of reform, in particular those of systemic importance. The reform should not be in sake of reform, or of moving to the Bologna process, but of higher quality of higher education, which would ensure the vital success of a person and society as a whole. This implies a large-scale inventory of education, its objective monitoring, with a possible structural reorganization and the completion of its individual units. Of course, the content of education should come first in the epicenter of all educational transformations. Incorporated in state standards, curricula, textbooks and other methodological resources, it should be constantly updated in accordance with the needs of each particular period. However, this dynamism of change is possible only by avoiding excessive centralization in determining the content of education. The new, modernized model of education should be built on two levels: normative (national) and elective (regional), which should be exclusively the competence of regions and educational institutions. At the same time, the national component of the educational content, which should provide a uniform level of fundamental education, should not exceed $70 \%$, and the elective part should be up to $30 \%$. Only such model can change the orientation of the initial process, ensure the use of the acquired knowledge for practical life (both professional and public), be mobile and flexible to the change in the integration of education, science, production, and make educational institutions become much more active in the reorientation to the training 
of deficit market professionals. Such a model should become one of the vectors of the education reforming strategy.

Another, equally important vector in this case should be the creation of educational and industrial groups (universities and enterprises), which would unite by the principle of joint participation their tangible and intangible assets for the implementation of investing and other projects and programs aimed at improving the quality of training specialists as well as improving the material and technical base and infrastructure. Certain sectoral educational and professional groups could include, in addition to higher education institutions, vocational schools, general education schools, comprehensive retraining courses, etc. All this would contribute to expanding the practice of social partnership with employers, involving the latter in the development of higher education curricula, to developing soft skills for students through the development of appropriate programs, to engaging company representatives in conducting classes (lecturing, work shopping), to introducing internship programs for tutors in companies for acquiring (mastering) practical experience.

The third step. Based on the current state of Ukrainian higher education and taking into account the processes of its "massiveness", separation from life and branch sprawl, the most important strategy in the modernized model should be a detailed inventory and optimization of the network of higher education institutions. The latter should be carried out through consolidation, enlargement on the basis of a special state target program, not only because we have many institutions of higher education (this is not such a big problem), but because there are few powerful universities in Ukraine that would be competitive in the educational world. The optimization criterion should be the effectiveness and quality of educational and scientific activity of the higher educational institution. After all, equal and fair access in the case of poor quality education loses any meaning.

In this regard, it would be advisable to differentiate all institutions of higher education into two types: a) higher professional schools; b) classical universities of national importance. The former should be oriented towards the needs of industrial production, agro-industrial complex, service sector, social sphere, etc. The latter should provide the training of scientists and specialists of the latest technologies for the hightech sector of the economy, use special approaches to the selection of students, create conditions for individualization of training. They should deviate from the traditional terms and methods of the mass higher education system, maximally approximate the forms of teaching to practical experience, actively implement methods of analysis of atypical situations, simulation modelling, which would be combined with theoretical and conceptual discussions. At the same time, these universities could substantially enhance their fundamental superiority over other higher education institutions, namely: to work on the long-term personal development of creative and innovative students.

Only under such conditions, higher education can become a proactive system, since its response to the social, socio-natural conditions is the foresight, sensitive capture of the attractive energy of the desired future, rather than adaptation to what is happening. It should rely on the processes, which determine the image of the XXI century: globalization and ethno-renaissance, informatization and the formation of the world culture, a strict limitation of technology and the creation of qualitatively new technologies. That is, all that the authors of the report of the Roman club "Come on!” (2017) emphasize on and all that the concept of University 3.0, which is already visible on the horizon, implies (Kvit, 2018). 


\section{REFERENCES}

Collini, S. (2011). The Dismantling of the Universities: From Robbins to McKinsey. London Review of Books, 33 (16), 9-14. Retrieved from (accessed 16 October 2018).

Eagleton, T. (2015). Medlennaya smert' universiteta [Slow death of the university]. Nauchnoprosvetitel'skij zhurnal "Skepsis". Retrieved from (accessed 16 October 2018).

Kvit, S. (2018). Road map of Ukraine's higher education reform. University World News, 497. Retrieved from (accessed 23 March 2018).

Nikol'skij, V. S. (2010). Kommodifikaciya znaniya i obrazovaniya: ehsse o cennostyah i cenah. Commodification of knowledge and education: essay on values. Higher education in Russia, 3, 149-152.

Ridings, B. (2009). Universitet v ruinah [University in ruins]. Minsk: BGU Publishing. (in Russian)

Robinson, K. \& Aronica, L. (2016). Shkola maibutnoho. Revoliutsiia u vashii shkoli, shcho nazavzhdy zminyt osvitu. [The school of the future, revolution in your school that will permanently change your education]. Lviv: Litopys. (in Ukrainian)

Saukh, P. Yu. (2012). Suchasna osvita: portret bez prykras: monohrafiia [Modern education: a portrait without decoration: a monograph. Zhytomyr: Vydavnytstvo ZhDU im. I. Franka. (in Ukrainian)

Saukh, P. Yu. (2017). Vyshcha osvita v ochikuvanni maibutnoho renesansu: problemy y perspektyvy. Ukrainskyi kontekst [Higher education in anticipation of the future of the Renaissance: problems and perspectives. Ukrainian context]. Naukove zabezpechennia rozvytku osvity $v$ Ukraini: aktualni problemy teorii i praktyky (do 25-richchia NAPN Ukrainy). Zbirnyk naukovykh prats [Scientific support for the development of education in Ukraine: actual problems of theory and practice (to the 25th anniversary of the National Academy of Sciences of Ukraine). Collection of scientific works]. Kyiv: Publishing House "Sam", 328-344.

Von Weizaecker, E. \& Wijkman, A. (2018). Come on! Capitalism, Short-termism, Population and the Destruction of the Planet. Springer. 